\title{
DYNAMICS OF WOOD EXPORT IN NIGERIA (1962-2017): AN ECONOMETRIC ANALYSIS
}

\author{
Idumah F.O.*, Awe F., Orumwense L.A. \\ Forestry Research Institute of Nigeria, Ibadan, Nigeria \\ *E-mail: femray4real@yahoo.com
}

\begin{abstract}
Nigeria is endowed with natural resources which include timber which has contributed in a significant way to the economy. This study examined the dynamics of wood export from 1962 to 2017. Secondary time series data obtained from FAOSTAT (Food and Agriculture Organization Statistics) were used for the study. The data were analyzed using some econometric tools such as Autoregressive Integrated Moving Average (ARIMA) models and subjected to Augmented Dickey Fuller (ADF) test. Results revealed that the future volume of sawn wood export is significantly determined by its previous two lagged values. In other words, the current quantity or value of export of sawn wood will be determined by the previous two quantities of export. It was also observed that there were series of upward and downward movements in export volumes of sawn wood over the period of study. The study shows that Nigeria will continue to witness decline in wood export over a period of time. Decline in wood export can only be halted if there is a drastic intervention by the government and other stakeholders to invest in plantation establishment and an effective forest management mechanism put in place for a sustainable management of this valuable renewable resource.
\end{abstract}

\section{KEY WORDS}

Forest resources, time series, sustainable management, moving average, augmented dickey fuller, unit root.

Forestry sector provides employment opportunities for thousands of Nigerians. In addition to this, it plays a variety of vital roles in rural development through provision of food and fodder, medicine, fuel wood, timber, game and wildlife and raw materials for industries (Emeghara, 2012). Nigeria has therefore benefitted immensely from forests and forest products, especially in terms of trade in timber which has contributed immensely to the Nigerian economy in terms of exports and also domestically as a source of raw materials to wood based industries like pulp and paper, furniture, match, and the saw-milling industries etc. (FVTC, 1996; Yusuf and Edom, 2007; Idumah and Awe, 2017).

Over the years, timber industry has contributed significantly to the socio-economic development of Nigeria ranking among the highest revenue and employment generating sectors (Fuwape, 2003 and FAO, 2006). It has also been a major contributor to the national gross domestic product (GDP) (Ofoegbu, 2014). Kalu and Okojie, 2009 also noted that the forestry sector used to contribute at least two-thirds of the GDP in addition to providing employment for thousands of Nigerians in the 1970s while Bichi (2011) asserted that timber trade is profitable and thus a formidable tool for poverty alleviation.

Nigeria is Africa's largest wood producer with an annual harvest estimated in 1998, of more than 100 million cubic meters (Aroufor, 2001). Nigeria used to be a major exporter of timber resources with industrial round wood export in 1964 at 781,200 m3and a corresponding value of US\$36.10 million. Nigeria ranked second amongst the seven largest tropical wood producing countries in Africa in 1966 (Adeyoju, 1975).Log exports were high during the 1960's, with a peak in exports of between $773,000 \mathrm{~m} 3$ and $781,200 \mathrm{~m} 3$ in 1964, with a value of about US\$ 18 million. By 1970 , the forestry sector generated about $2.5 \%$ of Nigeria's Gross Domestic Product (GDP), with wood and wood product exports accounting for about $1 \%$ of total foreign exchange earnings. However, the advent of trade in petroleum has led to a decline in timber exports over the years. Although production of industrial round 
wood had doubled from 1962to 1971, the value of logs, lumber and plywood exports had fallen from N13.8 million to N6.8 million (Popoola, 2018).

The value of forest product imports over the same period increased from N12.4 million to N31.8 implying that Nigeria became a net importer of forest products. In 1976, the Government banned the export of unprocessed logs of indigenous species logs and rough sawn lumber to protect supplies of round wood to the local market, which was expanding fast because of increase in local purchasing power and an expansion in the construction industry. This led to some reduction in exports (Popoola, 2018). In 1985, there was a further ban on all wood product exports (whether processed or not), excluding only furniture components and Gmelina wood. However, in the early 1990's to the end of that decade, there was an upsurge in the extraction and export of Teak.

Much of this trade was not properly controlled, so it is difficult to assess the volumes that were extracted and exported with any accuracy. It was fraught with a lot of irregularities that did not make accounting easy. Timber processing industries are permitted to export semi-finished or finished products, which are principally flooring planks/parquettes produced from Iroko and Afzelia. Export of teak and Gmelina logs is also permitted. Nigeria is a very convenient market for Ghana, with high prices paid and no concern about the legality of raw materials.

The current level of demand for wood has outstripped the sustainable level of supply and this situation is expected to deteriorate further. The projected level of demand for wood in the year 2020 is 180 million $\mathrm{m}^{3}$ against a sustainable level of supply of less than 100 million $\mathrm{m}^{3}$. The rapid rate of deforestation in the country (approximately $3.5 \%$ per annum) translates into an average loss degradation of 350,000 ha to 400,000 ha of forest cover every year. These trends do not support the government policy of maintaining $20-25 \%$ of the land area under forest cover for the well-being of the national, regional and global environment. There is therefore the need to assess the trend in wood export in Nigeria. Study by Rodrigue and Soumonni (2012) highlights the relationship between export and investment in mitigating negative outcomes on the natural environment.

This study therefore examined the dynamics of wood export from Nigeria to the global market's demand for tropical timber products. Specifically, it is to examine movements in export volume of sawn wood in Nigeria from 1962 to 2017, identify factors that influenced the movements and to predict future movement in export volume of timber exports in Nigeria up to 2040 .

\section{METHODS OF RESEARCH}

Data for this study are time series data on export volume of sawn wood (hardwood) from Nigeria which were obtained from FAOSTAT database and covered from 1962 to 2017.

Time series model is more common in using past movement of variables as a way of predicting future values. Contrary to structural models which relate to the model at hand to forecast, time series models are not necessarily rooted on economic theory. The reliability of the estimated equation is normally based on out-of-sample forecast performance as first observed by Stock and Watson (2003). Times series are mostly expressed by Autoregressive Moving Average (ARMA) models which were first produced by Slutsky (1927) and Wold (1938) as expressed in the following equation:

$$
Y_{t}=e_{t}-\theta_{1} e_{t-1}-\theta_{2} e_{t-2}-\theta_{3} e_{t-3} \ldots \ldots-\theta_{q} e_{t-q}
$$

Such a series is referred to as a moving average of order $\mathrm{q}$, with the nomenclature MA (q); where $Y_{t}$ is the original series and et as error term in the series. As Yule (1926) suggested, the autoregressive process of the moving average series can be expressed as:

$$
\mathrm{Yt}=\phi 1 \mathrm{Yt}-1+\phi 2 \mathrm{Yt}-2+\phi 3 \mathrm{Yt}-3+\ldots \ldots+\phi p \mathrm{Yt}-\mathrm{p}+\mathrm{et}
$$

It is assumed that $t$, is independent of $\mathrm{Y}_{\mathrm{t}-1}, \mathrm{Y}_{\mathrm{t}-2}, \mathrm{Y}_{\mathrm{t}-3}, . . \mathrm{Y}_{\mathrm{t}-\mathrm{q}}$. 
Here, we are trying to fit the Box-Jenkins Autoregressive Integrated Moving Average (ARIMA) model, which is the generalized model of the non-stationary ARMA model represented by ARMA $(p, q)$ and this can be written as:

$$
\mathrm{Y}_{\mathrm{t}}=\phi_{1} \mathrm{Y}_{\mathrm{t}-1}+\phi_{2} \mathrm{Y}_{\mathrm{t}-2}+\phi_{3} \mathrm{Y}_{\mathrm{t}-3}+\ldots+\phi_{\mathrm{p}} \mathrm{Y}_{\mathrm{t}-\mathrm{p}}+\mathrm{e}_{\mathrm{t}}-\theta_{1} \mathrm{e}_{\mathrm{t}-1}-\theta 2 \mathrm{et}-2 \ldots . .-\theta_{\mathrm{p}} \mathrm{e}_{\mathrm{t}-\mathrm{p}}
$$

Where, $Y_{t}$ is the original series, for every $t$, we assume that is independent of: $Y_{t-1}, Y_{t-2}, Y_{t-3}$, ... $\mathrm{Y}_{\mathrm{t}-\mathrm{p}}$.

Forecasts from Autoregressive Integrated Moving Average (ARIMA) models are optimal forecasts. This means that no other univariate forecasts have a smaller meansquared forecasts error (Shumway and Stoffer, 2010). ARIMA model was popularized in the landmark work by Box and Jenkins (1970). Therefore, the Autoregressive Integrated Moving Average (ARIMA) models which is usually known as the Box-Jenkins approach has become popular, especially with the advent of computer (Gooijeret. al.2006). ARIMA models are useful in building sufficient number of samples which Box and Jenkins suggested that the minimum sample size should be 50 observational data points. The first step to using the BoxJenkins model is to determine whether the time series data used are stationary or not stationary.

Test for data stationarity was performed using a unit root test by Dickey-Fuller. Data is stationary if the absolute value of the Augmented Dickey Fuller (ADF) Test Statistic is greater than absolute value of $t$ statistic with the critical value at $\alpha=1 \%$. If the data is not stationary, it is made stationary by doing logarithm transformation and differencing. The model is then estimated when the data is stationary.

Data were analyzed using Autoregressive Integrated Moving Average (ARIMA) method, popularly known as the Box-Jenkins Approach and the statistical package used in the analysis was Eviews10 (StudentLite Version). The best ARIMA model was then used to predict the value of timber export for the next five years.

\section{RESULTS AND DISCUSSION}

Figure 1 shows the trend in export volume of sawn wood in Nigeria from 1962 to 2017 and moving average forecast till 2040. Upward and downward trends can be observed throughout the period. From the graph, it can be observed that there was increase in export volume from 1962 to 1970 before there was decline in export volume between 1970 and 1980. The increase in export volume observed from 1962 to 1970 could be attributed to increase in the production of industrial round wood which almost doubled from1962 to 1971(Popoola, 2018). However, the decline observed between 1970 and 1980 could be due to the ban placed by government of Nigeria on the export of unprocessed logs of indigenous species and rough sawn lumber so as to protect supplies of round wood to local market which was rapidly expanding owing to expansion in the construction industry in the country. There was a relative stability in export volume between 1980 and 2000; after which export volume began to rise until it declined in 2010 until it began to decline in 2017. The stability and slight increase in export of timber observed from 1980s up till early 2000 may be due to upsurge in the production and export of teak, in spite of the prohibition placed on the export of timber, whether processed or semi-processed, by the government, with the exclusion of furniture components and species of Gmelinaarborea. However, decline in export volume of timber is further projected to continue until 2030 after which there is the likelihood of a rise until 2040, as depicted by the moving average. The project decline in export volume up till 2030 could be attributed partly to the current ban placed on Nigeria by the Convention on International Trade in Endangered species of Wild Fauna and Flora (CITES) from exporting some wood species, such as Pterocarpus erinaceus, which are considered to be endangered species. In addition, the decline could also arise as a result of the near non-availability of mature timber species suitable for export, as most mature tree species in Nigerian forests have been depleted. The projected rise in export volume from 2030 upward may be actualize if the government places emphasis on the development of forest plantations, especially ones 
planted with fast-growing exotic species such as Teak and Gmelina which possibly could have become mature and suitable for harvest and export by that time.

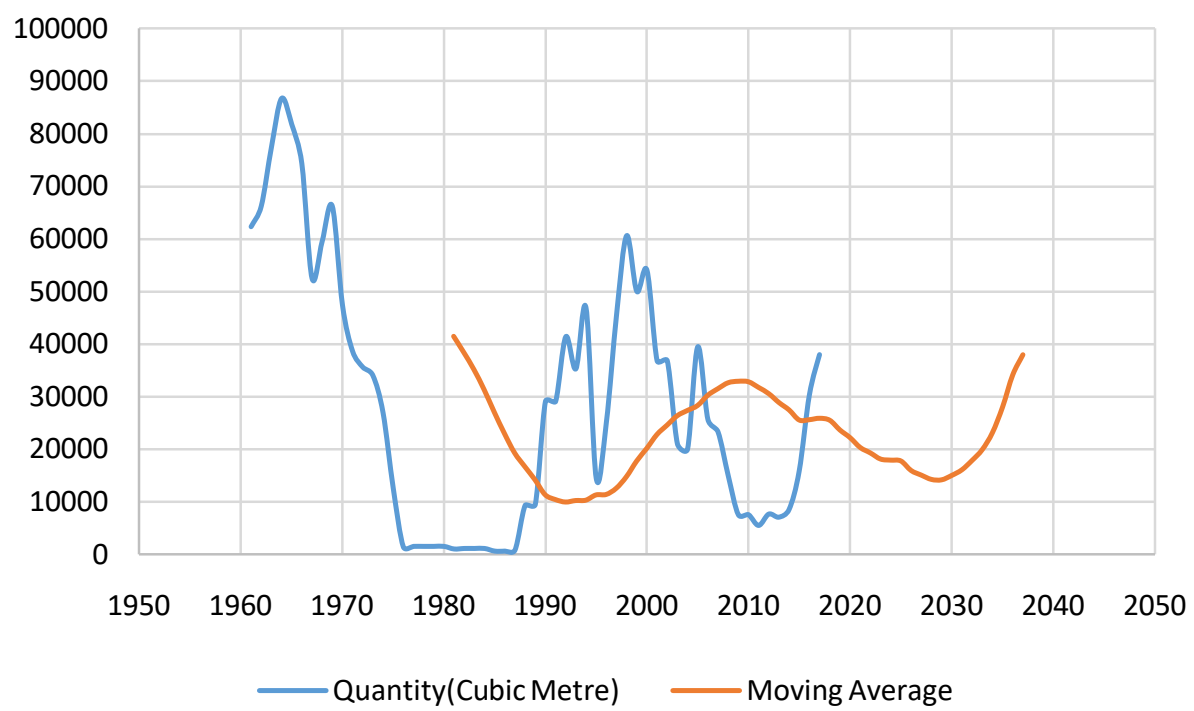

Figure 1 - Export Volume of Sawn wood from Nigeria (1962-2017)

The unit root or stationarity test was conducted using the Augmented Dickey Fuller (ADF) unit root test approach. This was used to determine whether a time series is stationary or not. The null hypothesis is that the variable observed has a unit root, against the alternative that it does not. Table 1 shows the results of test of the series (in logarithms) for unit roots using ADF Test (Dickey and Fuller 1979, Fuller1976). The test result indicates that the series is non-stationary at its level form but stationary after first differencing. Therefore, the order of integration is one and the variable is said to be integrated of the first order. That is I (1). This therefore indicates that ARIMA is the appropriate methodology to be applied as opposed to ARMA. The result is therefore in line with earlier study by Idumah and Awe (2017) where time series data examined were integrated of the first order and became stationary after first differencing. This further corroborates the works by Mafimisebi (2002),Adeoti and Owoyemi (2006) and Ghafooret al (2009) that time series data are usually integrated of order one and are often stationary after first differencing (Hussain,2010; Mehmood, 2010).

Table 1 - Augmented Dickey Fuller (ADF) Unit Root Tests

\begin{tabular}{lllll}
\hline Variable & Coefficient (level form) & Decision & Coefficient (At $\mathbf{1}^{\text {st }}$ difference) & Decision \\
\hline LTimExp & -1.518835 & Non-stationary & -6.600274 & Stationary \\
\hline
\end{tabular}

Eviews 10 Statistical Package Output; Critical value at $1 \%$ is -3.552666

The Automated ARIMA forecast process was used in selecting the best model for the data and this process selected $(2,1,1)$ as the best model, as shown in Table 2 .

This analysis is a univariate approach with single variable, which is the export volume of sawn wood from Nigeria and for which the lag is used to determine future occurrences. The estimation output below $(2,1,1)$ in Table 2 is considered the best after series of iterations, with the lowest AIC value and an Inverted AR Root value $<1$. In other words, there is a two AR processes and one MA process integrated to first difference as shown in the Augmented Dickey Fuller unit test. From the result, it can be observed that the second lag of the Autoregressive model (AR (-2)) is significant. This implies that the future export volume of sawn wood from Nigeria can be determined by its two lagged values. This implies that 
whatever volume of sawn wood to be exported this year will be determined by the previous two years volume of export.

Table 2 - Automatic ARIMA Output for Export Series

\begin{tabular}{lllll}
\hline Type & Coefficient & SE of Coefficient & $\mathbf{t}$ & $\mathbf{p}$ \\
\hline $\mathrm{C}$ & 8.323752 & 1.133681 & 7.342236 & 0.0000 \\
$\mathrm{AR}(1):$ & 0.350617 & 0.194163 & 1.805786 & 0.0767 \\
$\mathrm{AR}(2):$ & 0.475347 & 0.146233 & 3.250621 & 0.0020 \\
$\mathrm{MA} \mathrm{(1):}$ & 0.999999 & 1520.682 & 0.000658 & 0.9995 \\
SIGMASQ & 0.340023 & 15.03948 & 0.022609 & 0.9820 \\
\hline$R^{2}=0.872959$ & Inverted AR Roots $=0.89$ & \\
Adjusted $R^{2}=0.863186$ & Inverted MA Roots $=-1.00$ &
\end{tabular}

Source: Eviews 10

\section{CONCLUSION}

The paper examined the trend and movements in export volumes of sawn wood in Nigeria from 1962 to 2017 and made projection of the trend up to year 2040, using moving average. The study also used the ADF technique to test for stationarity of the series. The result of the unit root therefore suggests that the series was not stationary at its level form but became stationary after first differencing. Automatic ARIMA modelling approach was then used to model the sawn wood export series and this produced ARIMA $(2,1,1)$ as the best model. In addition, the results show that the future volume of sawn wood export is significantly determined by its previous two lagged values. In other words, the current quantity or value of export of sawn wood will be determined by the previous two quantities of export. It was also observed from the study that there were series of upward and downward movements in export volumes of sawn wood over the period of study. Owing to these trends and with downward trend in volume of timber export currently observed, which could be attributed to decline in availability of timber in Nigerian forests, it is therefore recommended that policies favorable to adequate financing of the forestry sector that produces the timber for export should be made and implemented by the Nigerian governments, both at the federal, state and local government levels, so as to increase timber production, especially the fast growing species and make them available for sustainable export. A robust mechanism should be put in place to ensure that the remaining natural forest resources are conserved and sustainably managed.

\section{REFERENCES}

1. Adeoti, A.I. and Owoyemi, J.B. (2006).Integration of Milled Local Rice Markets in Southwest Nigeria. Journal of Rural Economics and Development. 15(2):37-4.

2. Adeyoju, S.K. (1975). Forestry and Nigerian economy, 1st edition, Ibadan, Ibadan university press, pp: 305.

3. Aruofor, R. O. (2001): Forestry Outlook Paper, Nigeria. FOSA Working Paper, Ministry of Natural Resources and Tourism 31p.

4. Bichi A.M. (2011). Timber and non-timber products as tools for the eradication of poverty: A millennium development goal approach. Proceedings of the 38th annual conference of forestry association of Nigeria held in Osogbo, Osun State, Nigeria. (ed) L. Popoola; 147155. 
5. Box, G. E. P. and G. M. Jenkins. (1976).Time Series Analysis: Forecasting and control. Rev. ed. San Francisco: Holden-Day.

6. Dickey, D.A. and Fuller, W.A. (1979). Distribution of the Estimators for Autoregressive Time Series with a Unit Root. Journal of the American Statistical Association, 74, No. (366), pp. 423-431.

7. Food Agricultural Organization (2006). The State of Food Insecurity in the World. ISBN 92-5-105580-7. Available from http://www.fao.org/3/a-a0750e.pdf.

8. Fuller, W.A. (1976): Introduction to Statistical Time Series, Willey, New York.

9. Fuwape, J.A. (2003). The impacts of forests industries and wood utilization on the environment. Paper presented at the XII World Congress 2003, Quebec City; 2003.

10. FVTC (1996): Proceedings of a workshop on "Role of Women in Forestry and Environment Development". Forestry Vocational Training Centre (FVTC) Doraji, Kano, pp 86.

11. Ghafoor, A., K. Mustafa, K. Mushtaq and Abedullah. (2009). Co-integration and causality: An application to major mango markets in Pakistan. Lahore J. Econ. 14(1): 85-113.

12. Gooijer, Jan G. De and Rob J. Hyndman (2006).25 Years of Time Series Forecasting. International Journal of Forecasting 22, 443-473. Australia: Monash University.

13. Hussain, B. (2010). Testing the Law of One Price in Gram Markets of Pakistan. MPRA Paper No. 30708 posted 04. May 2011.

14. Idumah, F.O. and Awe, F. (2017). Contribution of Timber Exports to Economic Growth in Nigeria: an Econometric analysis. Journal of Research in Forestry, Wildlife \& Environment Vol. 9(4), pp.46-55. http://www.ajol.info/index.php/jrfwe. ISBN: $2141-1778$.

15. Kalu, C. and C. Okojie, (2009). Economic contributions of forests in Nigeria 1970-2000. Research Journal of Social Sciences, 2009, INSInet Publication, 4: 69-73.

16. Mafimisebi, T. (2002). Rural Infrastructure and Poverty Reduction in Nigeria, In Okunmadewa F. University Press. (2002) (Ed) Poverty Reduction and the Nigeria Agricultural Sector, Elshaddai Global Ventures Ltd, Ibadan, Nigeria.

17. Mehmood, A. (2010) Are Punjab Rice Farmers Benefited from Agricultural Trade Reforms: Analysis via Price Transmission in Selected Rice Markets in Punjab, Pakistan. M.Sc Thesis, Department of Agri. Economics, Faculty of Agri. Economics and Rural Sociology, University of Agriculture, Faisalabad.

18. Ofoegbu C. (2014). An analysis of the role of green economy in promoting innovative forest development in Nigeria: A synthesis from the literature. International Journal of Research in Earth and Environmental Sciences (IJREES); 1(5)1-2. Available: http://www.ijsk.org/ijrees.html.

19. Popoola, L. (2018). Free Trade agreements and Wood export in West Africa: Nigeria as a case study. Accessed on http://www.itto.int/files/topics/4901_ext_08_18.pdf.

20. Rodrigue, J., Soumonni, O. (2014). Deforestation, Foreign Demand and Export Dynamics in Indonesia. Journal of International Economics. 93. 10.1016/j.jinteco.2014.03.004.

21. Shumway, Robert H. and David S. Stoffer (2010). Time Series Analysis and Its Applications with R Examples. Third Edition. USA: Springer.

22. Slutsky E. E. (1927).Slozhenie sluchainykh prichin, kakistochniktsiklicheskikh protsessov. Voprosy konyunktury, 3(1927), 34-64.

23. Wold, H. (1938). A study in the analysis of stationary time series. Doctoral Thesis, Uppsala: Almqvist \& Wiksell.

24. Yusuf, A.S. and Edom, C.O. (2007). Determinants of Timber Exports in Nigeria: an Error Correction Modelling Approach. Munich Personal RePEc Archive, Paper No 2608, posted 6 April, 2007. 